\title{
Hydrogen Generation through Electrolysis of Brine for Clean Energy Development in a Depressed Economy
}

\author{
Koleola Ebenezer Ojaomo ${ }^{1}$, Tunji John Erinle ${ }^{2}$, Dayo Hephzibah Oladebeye ${ }^{3}$, \\ Oluwasayo Dorcas Olakolegan ${ }^{4}$ \\ Lecturer I, Mechanical Engineering, The Federal Polytechnic, Ado-Ekiti, Ekiti State, Nigeria ${ }^{1}$ \\ Lecturer III, Mechanical Engineering, The Federal Polytechnic, Ado-Ekiti, Ekiti State, Nigeria ${ }^{2}$ \\ Chief Lecturer, Mechanical Engineering, The Federal Polytechnic, Ado-Ekiti, Ekiti State, Nigeria ${ }^{3}$ \\ Senior Technologist, Mechanical Engineering, The Federal Polytechnic, Ado-Ekiti, Ekiti State, Nigeria ${ }^{4}$
}

\begin{abstract}
The study focused on production of hydrogen gas by means of water hydrolysis using electrolysis of brine. The alarming negative effect of hydrocarbon on the earth is on the rise every day. Hydrogen gas burns cleaner than hydrocarbon sources and it provides a solution to the problems constituted by other carbon emitting fuels. Therefore, a need to develop a hydrogen generator working on the principle of water hydrolysis for energy generation which is free from environmental hazards was considered. Hydrogen gas was produced from hydrolysis of water using aluminium electrode and brine as an electrolyte. The match test was used to detect the hydrogen gas produced during the experimentation. Therefore, the hydrogen gas generated from hydrolysis of $250 \mathrm{~g}$ of $\mathrm{NaCl}$ in 21600 seconds yielded mass of 2.7 grams with equivalent of 1.4 mole and volume of $30 \mathrm{dm}^{3}$. It was observed that the higher the current passed the more the hydrogen produced when the concentration of conducting solution remains constant.
\end{abstract}

Keywords: Aluminium Electrodes, Clean Energy, Electrolysis of Brine, Hydrogen Gas, Water Hydrolysis,

\section{INTRODUCTION}

Hydrogen gas is a zero emission fuel devoid of greenhouse effect when burned with oxygen and can be generated very cheaply, though carefully, using hydrolysis of water which is abundant in nature. Production of hydrogen through renewable source like water electrolysis with no emission of $\mathrm{SOx}, \mathrm{NOx}, \mathrm{CO}_{2}$ and $\mathrm{CO}$ is worthwhile to achieve "hydrogen economy" [1;2]. Hydrogen is a chemical element that exists as a gas at room temperature. Hydrogen gas is odourless, tasteless, colourless, and highly flammable. When hydrogen gas burns in air, it forms water. French chemist Antoine Lavoisier named hydrogen from the Greek words for "water former" [3]. The escalation in global dependence on energy has remained a serious task worldwide over the years and the cost of providing a significant energy is alarming and highly expensive. Fuels are materials that undergo combustion to release energy and consists of chemical compound of hydrogen and carbon as their major constituents elements. From the perspective of climate and ecology, hydrocarbon fuels contribute great production of atmospheric carbon content, which has emerged in recent decades as the fastest greenhouse changing gas [4]. There is need to develop a clean fuel technology devoid of greenhouse gases production, such technology includes hydrogen fuels. Its combustion products do not cause ozone layers depletion.

Hydrogen is usually considered an energy carrier, like electricity, as it can be produced from a primary energy source such as solar energy, biomass or hydrocarbons such as natural gas or coal $[1 ; 5 ; 6]$. . The use of solar energy and wind energy are sustainable methods for hydrogen production by water electrolysis with high purity, simple and green process [7].

According to [8] conventional hydrogen production using natural gas induces significant environmental impacts, as with the use of any hydrocarbon, carbon dioxide is emitted [9]. It was observed that hydrogen possesses some attractive advantages such as abundance, environmentally friendliness and high calorific/heating value of $141.9 \mathrm{MJ} / \mathrm{kg}[10 ; 11$; 12].

[13] reported that an electrostatic machine to make electricity which was discharged on gold electrodes in a Leyden jar with water was used by Jan Rudolph Deiman and Adriaan Paets van Troostwijk. William Nicholson and Anthony Carlisle used the voltaic pile that was invented by Alessandro Volta for the electrolysis of water. Zénobe Gramme invented the Gramme machine as a cheap method for the production of hydrogen by means of electrolysis of water. An industrial 


\section{International Advanced Research Journal in Science, Engineering and Technology}

Vol. 7, Issue 4, April 2020

synthesis of hydrogen and oxygen production method through electrolysis was developed by Dmitry Lachinov [14]. The cleavage of a molecule by reaction with water or with insertion of the elements of water into the final products is called hydrolysis [15].

Hydrogen generation processes include steam reformation, partial oxidation, water electrolysis, gasification of woody biomass conversion, biological processes, photo dissociation, and direct thermal or catalytically water splitting [16; 17; $18]$.

[12] in his publication observed the following as the properties of hydrogen: hydrogen is an odourless, colourless gas with a molecular weight of 2.016 . It is the lightest element with a density about 14 times less than air $\left(0.08376 \mathrm{~kg} / \mathrm{m}^{3}\right.$ at standard temperature and pressure). Hydrogen is liquid at temperatures below $20.3 \mathrm{~K}$ (at atmospheric pressure). Hydrogen has the highest energy content per unit mass of all fuels with a higher heating value almost 3 times higher than gasoline.

Currently, hydrogen is mainly produced from hydrocarbons. Logical sources of hydrogen are hydrocarbon (fossil) fuels and water [19]. [20] stated that approximately $96 \%$ of hydrogen is produced from hydrocarbons such as natural gas, oil and coal) and $4 \%$ from electrolysis.

However, hydrogen produced from hydrocarbons yields carbon dioxide and minute quantities of carbon monoxide as byproducts [9]. [21] studied how to generate hydrogen by means of hydrolysis using activated aluminium alloy composites (Al-In-Bi-Sn) for electrochemical energy applications. The method adopted by [21] was mechanochemical activation method to prepare various $\mathrm{Al}$ composites containing $\mathrm{Bi}$, In and $\mathrm{Sn}$ as activation compounds. The hydrogen gas generated was investigated under standard temperature and pressure conditions. It was concluded that the gas generated of ballmilled aluminium $(\mathrm{Al})$ depended on the activation compounds. The formation of intermetallic phases is responsible for the structural failure of $\mathrm{Al}$, resulting in the size reduction of $\mathrm{Al}$ particles.

If the use of hydrogen as a future non-polluting energy carrier were to be realized, it has to be produced with relative ease from renewable sources using clean processes that limits or excludes carbon monoxide and dioxide formation [22; $23 ; 7]$. The hydrogen content of water $\left(111 \mathrm{~kg} / \mathrm{m}^{3}\right)$ exceeds that of gasoline $\left(84 \mathrm{~kg} / \mathrm{m}^{3}\right)$ and liquid hydrogen $\left(71 \mathrm{~kg} / \mathrm{m}^{3}\right)$, making it a potential hydrogen source [24]. Several water-based hydrogen production methods exist, e.g. metal and metal hydride hydrolysis, water photo-catalysis and water electrolysis [25; 26; 27].

For hydrogen production, water electrolysis has its various merits like pollution free process of renewable energy sources use purity of high degree, very simple process and plenty of resources [28]. About five percent of hydrogen gas produced worldwide is created by electrolysis. Currently, most industrial methods produce hydrogen from natural gas instead, in the steam reforming process [29].

Developed countries like Canada has set up a plant capable of producing 1.5 million tonnes of hydrogen per year in 2018 and many nations like Japan are still poised for huge commitment to produce commercially. Production of hydrogen as an energy carrier would require an increase in production rates by several orders of magnitude. A consistent source for large-scale hydrogen production is water, which is abundant on earth [12].

[30] reported that in electrolysis of pure water at the negatively charged electrode, a reduction reaction took place, with electrons $\left(\mathrm{e}^{-}\right)$from the cathode donated to hydrogen cations to form hydrogen gas. Also, at the positively charged anode electrode, an oxidation reaction occurred, generating oxygen gas and gave electrons to the anode to complete the circuit. Simple demonstration of electrolysis of water as shown in Fig. 1. This technique produces clean energy without emission of pollution by utilizing direct electric current converted from an alternating source.

The half reaction as given in equation 1 to 2

Reduction at cathode: $2 \mathrm{H}^{+}(\mathrm{aq})+2 \mathrm{e}^{-} \rightarrow \mathrm{H}_{2}(\mathrm{~g})$

Oxidation at anode: $2 \mathrm{H}_{2} \mathrm{O}(\mathrm{l}) \rightarrow \mathrm{O}_{2}(\mathrm{~g})+4 \mathrm{H}^{+}(\mathrm{aq})+4 \mathrm{e}^{-}$

The same half-reactions also was balanced as given in equation 3 and 4 .

Cathode (reduction): $2 \mathrm{H}_{2} \mathrm{O}(\mathrm{l})+2 \mathrm{e}^{-} \rightarrow \mathrm{H}_{2}(\mathrm{~g})+2 \mathrm{OH}^{-}$(aq)

Anode (oxidation): $2 \mathrm{OH}^{-}(\mathrm{aq}) \rightarrow \frac{1}{2} \mathrm{O}_{2}(\mathrm{~g})+\mathrm{H}_{2} \mathrm{O}(\mathrm{l})+2 \mathrm{e}^{-}$

Combining either half reaction pair yields the same overall decomposition of water into oxygen and hydrogen as given in equation 5 .

Overall reaction: $2 \mathrm{H}_{2} \mathrm{O}(\mathrm{l}) \rightarrow 2 \mathrm{H}_{2}(\mathrm{~g})+\mathrm{O}_{2}(\mathrm{~g})$ 

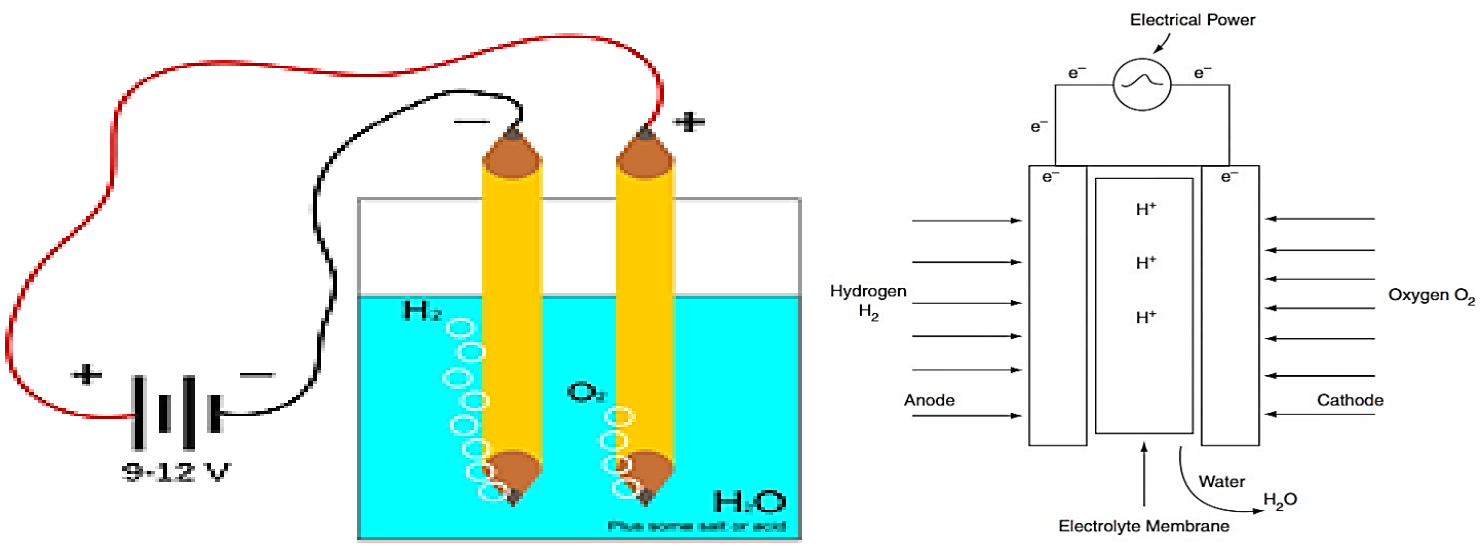

Fig. 1: Simple demonstration of electrolysis of water [30].

In this work, a portable hydrogen generating plant was developed; the salt solution-based hydrogen production method was electrolysis of brine, the plant materials were locally sourced and operated on electricity making it eco-friendly.

\section{A. Hydrogen as Fuel and Energy}

This has been suggested as a way of shifting society towards using hydrogen as an energy carrier for powering electric motors and internal combustion engines. Hydrogen fuel can be used in fuel cells or internal combustion engines to power electric vehicles or electric devices. It is also used as a fuel for spacecraft propulsion. Since hydrogen gas is so light, it rises in the atmosphere and is therefore rarely found in its pure form [31; 32]. Hydrogen is locked up in enormous quantities in water, hydrocarbons, and other organic matter [33]. One of the challenges of using hydrogen as a fuel comes from being able to efficiently extract hydrogen from these compounds [25]. Hydrogen can be produced from water through electrolysis, which is less carbon intensive if the electricity used to drive the reaction does not come from fossilfuel power plants but rather renewable or nuclear energy instead [18; 12].

In a flame of pure hydrogen gas, burning in air, the hydrogen $\left(\mathrm{H}_{2}\right)$ reacts with oxygen $\left(\mathrm{O}_{2}\right)$ to form water $\left(\mathrm{H}_{2} \mathrm{O}\right)$ and releases energy of heat of combustion -57.796 kilocalories per mole as given in equation 6 [34]. The overall chemical equation diagram as shown in Fig. 2. The Pourbaix diagram for water which include the equilibrium regions for water, oxygen and hydrogen at standard temperature and pressure (STP) as shown in Fig. 3.

$2 \mathrm{H}_{2}(\mathrm{~g})+\mathrm{O}_{2}(\mathrm{~g}) \rightarrow 2 \mathrm{H}_{2} \mathrm{O}(\mathrm{g})+$ Energy

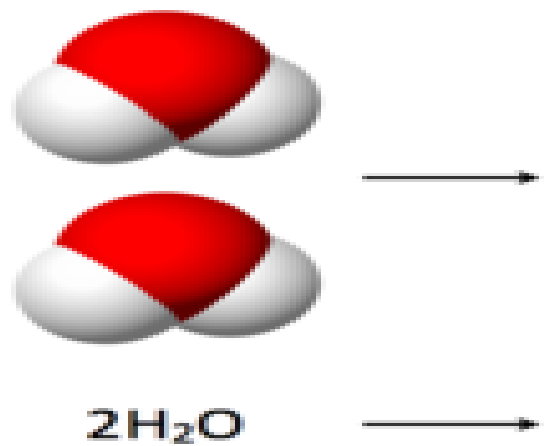

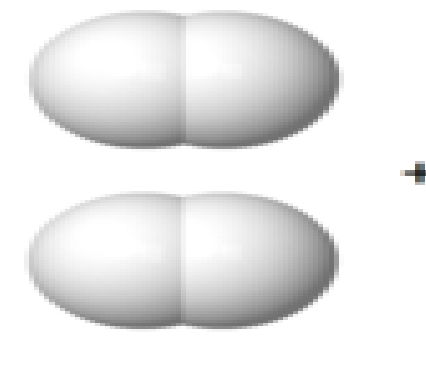

$2 \mathrm{H}_{2}$
6

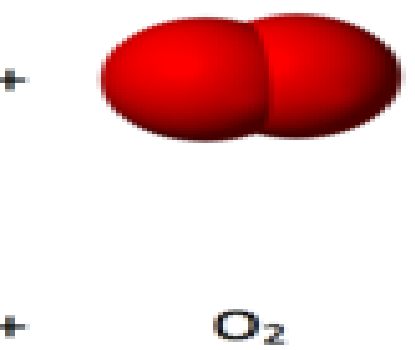

Fig. 2: Diagram Depict the Overall Chemical Equation [30]. 


\section{International Advanced Research Journal in Science, Engineering and Technology}

Vol. 7, Issue 4, April 2020

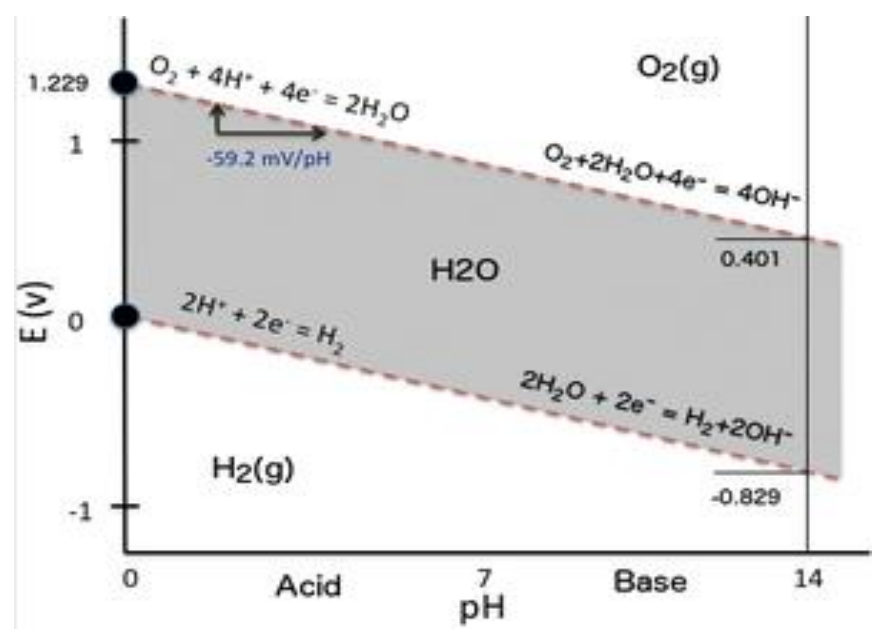

Fig. 3: Pourbaix Diagram for Water [35].

\section{A. Materials}

\section{MATERIALS AND METHODS}

The materials employed to produce hydrogen gas through the means of electrolysis of brine are the alternating current power supply, electrical power converter, production cylinder reactor, common (table) salt of 250 grams, water, aluminium electrodes and gas purification cylinder, measuring apparatus, sodium chloride salt, 5litres of distilled water and electrical wire. The developed apparatus for the production of hydrogen gas as shown in Fig. 4.

\section{Alternating Current (A. C.) Power Supply:}

Alternating current power supply is the main source of electrical energy of about 220 to 240 volts to the equipment.

\section{Electrical Power Converter:}

Electrical power converter is an electrical device which convert the alternating current to direct current for the supply of electricity to flow in one direction in the circuit.

\section{Direct Current (D. C) power Supply:}

Direct current power supply is an electrical power source connected to two aluminium electrodes which were placed in the water. The magnitude of the supplied D.C required is 12 volts.

\section{Production Cylinder Reactor:}

The production cylinder reactor houses the whole electrolyte and aluminium electrodes. The cylinder consists of electrolyte in molten state, a pair of electrodes. The decomposition of the electrode takes place inside this cylinder.

\section{Electrolyte:}

The electrolyte is the solution of salt and water to form brine.

\section{Aluminium Electrodes:}

The aluminium electrode is an electrical conductor that provides the physical interface between the electrical circuit providing the energy and the electrolyte. Two pieces of aluminium electrode are used as anode cathode to carry the electrical charge conducted by the solution.

\section{Gas Purification Cylinder:}

The gas purification cylinder contains water which was used to remove the moisture contained in the hydrogen gas to be produced. 
Vol. 7, Issue 4, April 2020

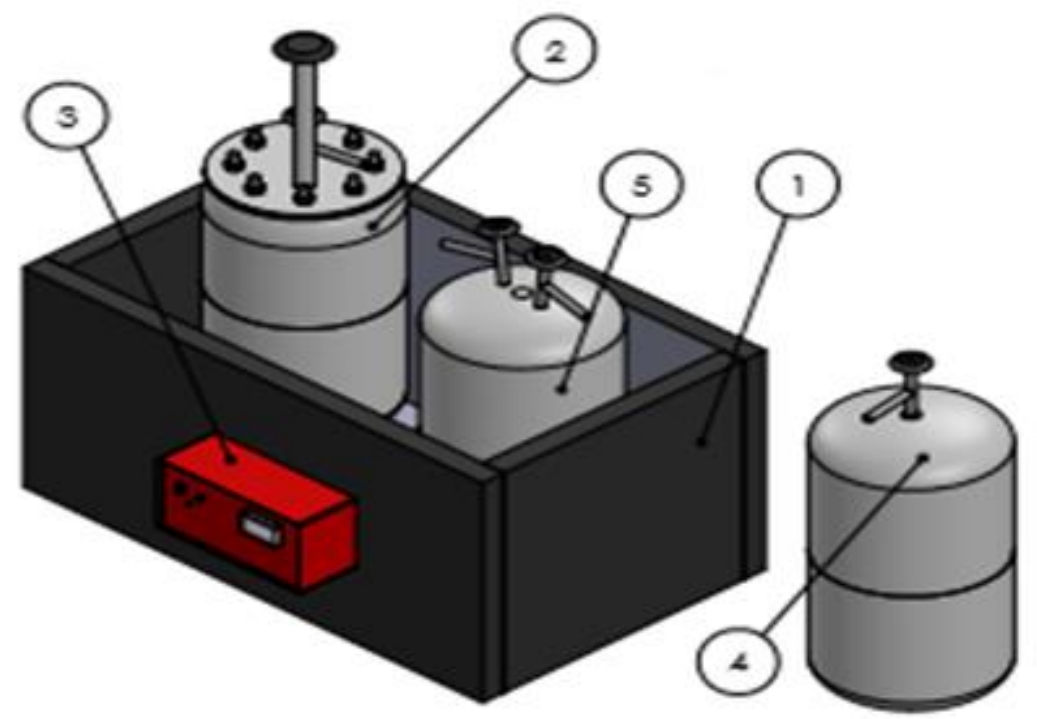

Fig. 4: Developed Apparatus for the Production of Hydrogen Gas

\section{B. Methods}

Electrolysis is a technique of separating bonded elements and compounds by passing an electric current through them. An ionic compound, in this case salt, is dissolved with an appropriate solvent, such as water, so that its ions are available in the liquid. An electrical current is applied between a pair of inert electrodes immersed in the liquid. The negatively charged electrode is called the cathode, and the positively charged one the anode. The energy required to separate the ions, and cause them to gather at the respective electrodes, is provided by an electrical power supply. At the probes, electrons are absorbed or released by the ions, forming a collection of the desired element or compound [32].

\section{Experimental Set-up and Procedure:}

Electrolysis of brine is the decomposition of sodium chloride solution into sodium ion, chlorine gas, oxygen gas and hydrogen gas due to the passage of an electric current. The common salt was dissolved in water and mixed homogenously in a bowl. The salt solution was then poured into the production cylinder reactor as an electrolyte. The two aluminium electrodes (anode and cathode) was connected and running from the terminals of 12 volts direct current power supply. The other ends of the electrodes was placed in a production cylinder with a quantity of electrolyte to establish conductivity in the solution [36]. The set-up for electrolysis of brine experiment in form of pictorial view as shown in Fig. 5.

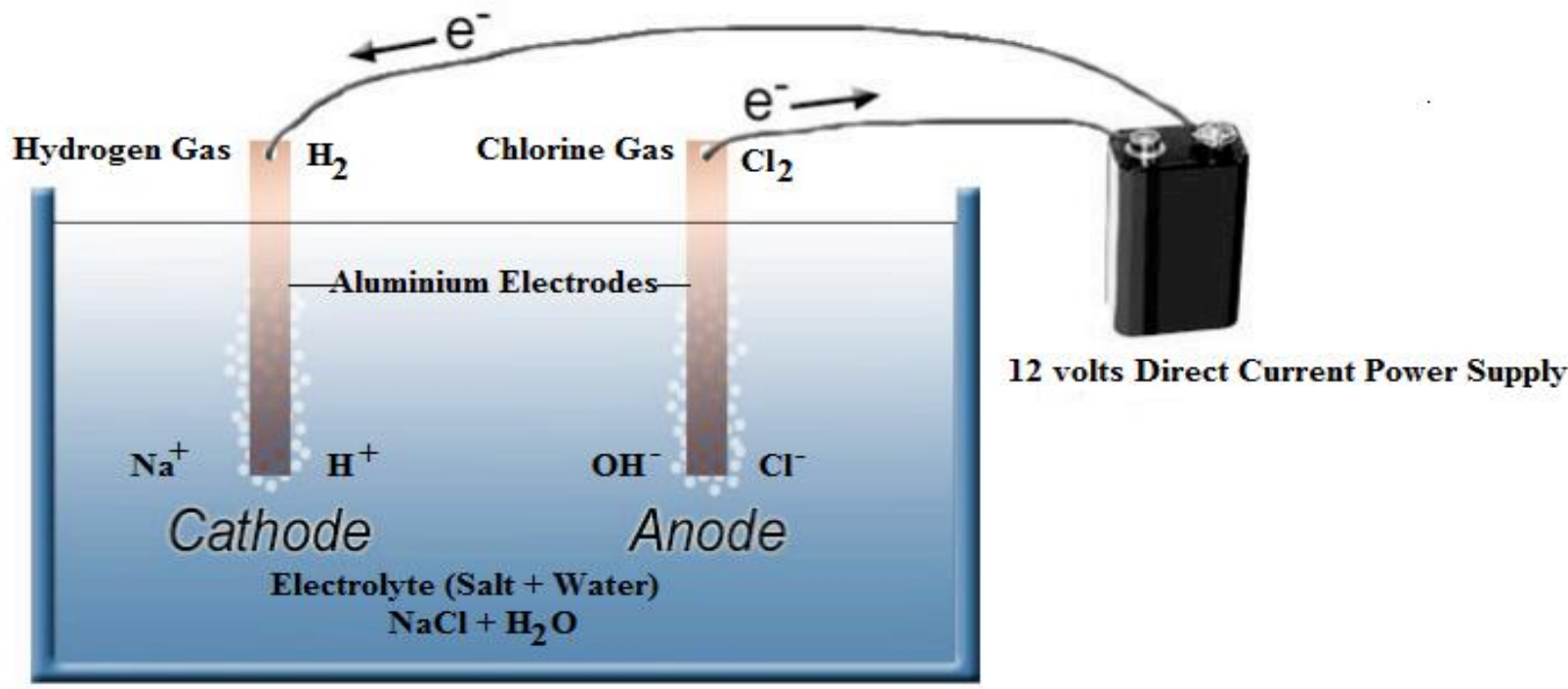

Fig. 5: Set-up for Electrolysis of Brine Experiment 


\section{International Advanced Research Journal in Science, Engineering and Technology}

Vol. 7, Issue 4, April 2020

The equation used to calculate the percentage composition by mass of salt needed to be added to water as given in equation 7 [32].

$\%$ mass of salt needed to be added to water $=\frac{\text { mass of the solute }}{\text { mass of the solution }}=$

$\%$ mass of salt needed to be added to water $=\frac{\text { mass of the solute (Salt) }}{\text { mass of the solute }+ \text { mass of the solvent (Water) }}$

$\%$ mass of salt needed to be added to water $=\frac{\text { grams of } \mathrm{NaCl}}{\text { grams of } \mathrm{NaCl}+\text { grams of } \mathrm{Water}} \times 100 \%$

The quantity of electricity required for the production of hydrogen through the developed reactor as given in equation 8 $[35 ; 37]$.

$Q=I t$

The amount of salt used to generate the hydrogen gas was 250 grams. The volume of water needed to mix with was 5 $\mathrm{dm}^{3}$ (5 litres).

The amount of salt in mole was determined using equation 9 [35; 37].

Mole of substance $=\frac{\text { Mass of substance }}{\text { Molar mass of the substance }}$

The amount of salt solution in mole/ $\mathrm{dm}^{3}$ was determined using equation 10 [35].

Molarity $\left(\right.$ mole $\left./ \mathrm{dm}^{3}\right)=\frac{\text { Mass of substance } / \mathrm{dm}^{3}}{\text { Molar mass of the substance }}$

The mass of hydrogen gas to be generated was calculated using Faradays law of electrolysis as given in equation 11 [35; 37].

Quantity of electricity, $Q=\frac{\text { Mass of subtance } \times \text { No of Faraday (Charges) }}{\text { Molar mass of the substance }}$

The volume of hydrogen gas to be generated was calculated using molar volume at standard temperature and pressure as given in equation $12[35 ; 37]$.

Volume of gas $=\frac{\text { Mass of subtance }}{\text { Molar mass of the substance }} \times 22.4 \mathrm{dm}^{3}$ STP

\section{RESULTS AND DISCUSSIONS}

Alternating current power supply was used to supply electrical energy of about 220 to 240 volts to the electrical power converter which stepped down the a. c. voltage to 12 volts. The direct current was supplied to the electrolyte through the two terminal electrodes. The current passed through the system was 12 amperes, the experiments was performed for the duration of 6 hours. The quantity of electricity required to produce charges in the system for 6 hours of operation was calculated to be 259200 Coulombs. The 250 grams of salt in one $\mathrm{dm}^{3}$ produced molarity of 4.3 mole per $\mathrm{dm}^{3}$.

Hydrolysis reactions were carried out at room standard temperature and pressure (STP) in a $13.5 \mathrm{~kg}$ cylindrical reactor with two openings, port A for electrolyte addition and the other port B for hydrogen to discharge. When current was run through the electrolysis of brine (solution of $\mathrm{NaCl}$ ), the positively charged sodium and hydrogen ions migrate to the cathode by gaining electrons to form sodium and hydrogen atoms. Then, the negatively charged chloride and oxygen ions migrate to the anode by losing electrons to form chlorine and oxygen atoms. The atoms join up in pairs to form hydrogen and chlorine molecules, so hydrogen and chlorine gas is formed at the cathode and anode respectively [37; 29]. These gases appeared on the immersed electrodes as very tiny bubbles around the tips. Oxygen is not given off in this experiment. That's because the oxygen atoms from the water combine in the liquid with the salt to form hydroxyl ions. The oxygen in the hydroxyl ions stay in the solution. The generated hydrogen gas passed through the purification cylinder containing water by downward delivery in order to remove water vapour from the hydrogen gas. The gas formed bubble and the liquid in it was trapped leaving only the hydrogen gas on top of the liquid layer to escape through the delivery port and then into the storage cylinder.

Reaction equations for the electrolysis of $\mathrm{NaCl}$ solution as given in equation 13 .

$2 \mathrm{NaCl}+2 \mathrm{H}_{2} \mathrm{O} \rightarrow \mathrm{Cl}_{2}+\mathrm{H}_{2}+2 \mathrm{NaOH}$

Ionic equations for the electrolysis of $\mathrm{NaCl}$ solution as given in equation 14 to 20

$\mathrm{NaCl} \rightleftharpoons \mathrm{Na}^{+}+\mathrm{Cl}^{-}$

$\mathrm{H}_{2} \mathrm{O} \rightleftharpoons \mathrm{H}^{+}+\mathrm{OH}^{-}$

The oxidation reaction equation

$2 \mathrm{Cl}^{-} \rightleftharpoons \mathrm{Cl}_{2}+2 \mathrm{e}^{-}$

The reduction reaction equation 


\section{International Advanced Research Journal in Science, Engineering and Technology}

Vol. 7, Issue 4, April 2020

$2 \mathrm{H}_{2} \mathrm{O}+2 \mathrm{e} \rightleftharpoons \mathrm{H}_{2}+2 \mathrm{OH}^{-}$

Cathode

$\mathrm{H}^{+}$atoms combine in pairs

$2 \mathrm{H}^{+}+2 \mathrm{e}^{-} \longrightarrow \mathrm{H}_{2}$

Anode

$\mathrm{Cl}^{-}$atoms combine in pairs

$2 \mathrm{Cl}^{-}-2 \mathrm{e}^{-} \longrightarrow \mathrm{Cl}+\mathrm{Cl}=\mathrm{Cl}_{2}$

The overall reaction equation

$2 \mathrm{Cl}^{-}+2 \mathrm{H}_{2} \mathrm{O} \Longrightarrow \mathrm{Cl}_{2}+\mathrm{H}_{2}+2 \mathrm{OH}^{-}$

$\mathrm{Cl}^{-}$is easier to oxidize than water, thus the product formed at the anode is chlorine gas. Water is easier to reduce than $\mathrm{Na}+$ ions being lower in the electrochemical series, thus the product formed at the cathode is hydrogen gas [32]. Hydrogen gas displaces water and collects at the top into a collection cylinder.

[29] affirmed that using sodium chloride $(\mathrm{NaCl})$ in an electrolyte solution results in chlorine gas rather than oxygen gas due to a competing half-reaction. It was reported that an aqueous solution of water with chloride ions, when electrolyzed, would result in either $\mathrm{OH}^{-}$if the concentration of $\mathrm{Cl}^{-}$is low or in chlorine gas being preferentially discharged if the concentration of $\mathrm{Cl}^{-}$is greater than $25 \%$ by mass in the solution.

According to [29], in the electrolysis of brine process a sodium chloride-water $\left(\mathrm{NaCl}-\mathrm{H}_{2} \mathrm{O}\right)$ mixture is only half the electrolysis of water since the chloride ions are oxidized to chlorine rather than water being oxidized to oxygen. Thermodynamically, since the oxidation potential of the chloride ion is less than that of water, but the rate of the chloride reaction is much greater than that of water, causing it to predominate.

At the cathode $\mathrm{Na}^{+}$and $\mathrm{H}^{+}$migrate to the cathode but $\mathrm{H}^{+}$is preferentially discharged being higher in the electrochemical series. Also, at the anode $\mathrm{Cl}^{-}$and $\mathrm{OH}^{-}$migrate to the anode in which $\mathrm{Cl}^{-}$get preferentially discharged.

The amount of hydrogen gas generated from the experiment was 2.7 grams and 1.35 mole. The volume of gas produced was $30 \mathrm{dm}^{3}$ at standard temperature and pressure.

The match test was used to detect the presence of hydrogen gas during the experiment to confirm the type of gas produce in which a pop sound and fire was given out as confirmatory sign as shown in Plate 1.

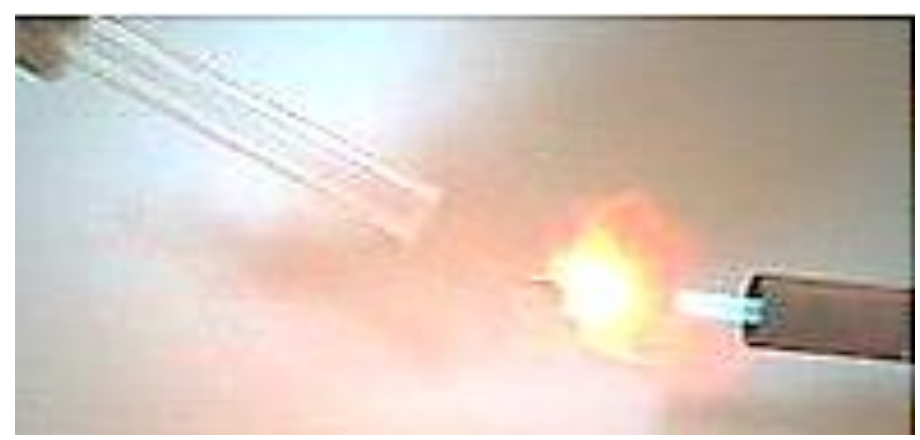

Plate 1: Match Test to Detect the Presence of Hydrogen gas

\section{CONCLUSION}

In the electrolysis of brine (Sodium Chloride solution) when a 250grams of $\mathrm{NaCl}$ was dissolved in $5 \mathrm{dm}^{3}$ (5 litres) of distilled water; a current of 12 ampere was passed through the electrolyte for 6 hours to generate 259200 Coulombs which in turn produced 2.7 grams of hydrogen equivalent of 1.4 mole. Hydrogen generation depend on the quantity of current passing through the electrolyte and the time taken. Hydrolysis reactions were relatively fast due to the presence of high current passing through the electrolyte to heat up rapidly and produced more hydrogen gas. It was concluded that the higher the current passage, the more the hydrogen to be produced when the conducted solution remains constant in concentration. 


\title{
International Advanced Research Journal in Science, Engineering and Technology
}

\author{
Vol. 7, Issue 4, April 2020
}

\section{REFERENCES}

[1]. Elam, C. C., Padró, C. E. G., Sandrock, G., Luzzi, A., Lindblad, P. and Hagen, E. F. (2003). Realizing the Hydrogen Future. International Journal of Hydrogen Energy, Vol. 28, pp. 601-607.

[2]. Kelly, N. A., Gibson, T. L., Cai, M., Spearot, J. A. and Ouwerkerk, D. B. (2010). "Development of a Renewable Hydrogen Economy: Optimization of Existing Technologies. International Journal of Hydrogen Energy; Vol 35: pp89- 99.

[3]. Encarta (2009). "Hydrogen". Microsoft Corporation, Washington D.C., USA.

[4]. Demirbas, A. (2009). Political Economic and Environmental Impacts of Biofuels: A Review. Applied Energy, Vol. 86, Issue Supplement 1, S108-S117.

[5]. Zehner, O., (2012). "Green Illusions". Lincoln and London, University of Nebraska Press.

pp.1-16.

[6]. Gosavi, P. V. and Biniwale, R. B. (2013). Catalytic Preferential Oxidation of Carbon Monoxide over Platinum Supported on Lanthanum Ferrite-Ceria Catalysts for Cleaning Hydrogen. Journal of Power Sources, Vol. 222 pp.1-9. dx.doi.org/10.1016/j.jpowsuor.2012.07.095.

[7]. Wang, M., Wang, Z., Gong, X. and Guo, Z. (2014). "The Intensification Technologies to Water Electrolysis for Hydrogen Production", Renewable and Sustainable Energy. doi.org/10.1016/j.rser.2013.08.090.

[8]. Wang, F. (2015). "Thermodynamic Analysis of High-Temperature Helium Heated Fuel Reforming for Hydrogen Production", International Journal of Energy Research, Vol. 39 Issue 3, pp. 418-432.

[9]. Ball, M. and Wietschel, M. (2009). The Future Hydrogen Opportunities and Challenges. International Journal of Hydrogen Energy. Vol. 34, Issue 2, pp. 615627. doi.org/10.1016/j.ijhydene.

[10]. Wang, H. Z. Leung, D. Y. C. Leung, M. K. H. and Ni, M. A. (2009). Review on Hydrogen Production Using Aluminium and Aluminium Alloys. Renewable and Sustainable Energy Reviews, Vol. 13, No 4, Issue 05, pp. 845-853.

[11]. Chai, Y. J. Dong, Y. M., Meng, H. X., Jia, Y. Y., Shen, J., Huang, Y. M. and Wang, N. (2014). Hydrogen Generation by Aluminium Corrosion in Cobalt (II) Chloride and Nickel (II) Chloride Aqueous Solutions. Energy, Elsevier, Vol. 68 (C), pp.204-209. doi.org/10.1016/j.energy.2014.03.011.

[12]. William, L. J. (2019). "Hydrogen", Encyclopeadia Britannica, Inc. http://www.britannica.com.

[13]. Levie, R. D. (1999). "The electrolysis of water". Journal of Electroanalytical Chemistry, Vol. 476, Issue 1, pp. 92-93. doi: 10.1016/S0022-0728(99)00365-4.

[14]. Lachinov, D. A. (2011). Encyclopedia. Wayback Machine at Great Cyrill and Methodius, Russian.

[15]. Encyclopeadia Britannica (2013). "Hydrolysis". Encyclopeadia Britannica Ultimate Reference Suite, Chicago, USA.

[16]. Turner, J. A. (2004). Sustainable Hydrogen Production. Science, Vol. 305, Issue 5686, pp. 972-974. doi.org/10.1026/science.1103197.

[17]. Chen, X., Zhao, Z., Hao, M. and Wang, D. (2013). Research of Hydrogen Generation by the Reaction of Al-Based Materials with Water. Journal of Power Sources, 222188 .

[18]. Sorensen, B. and Spazzafumo, G. (2018). "Hydrogen and Fuel Cells", Emerging Technologies and Applications. Academic Press.

[19]. Preez, S. P. and Bessarabov, D. (2018). "Hydrogen Generation by the Hydrolysis of Mechanochemically Activated Aluminum-Tinindium Composites in Pure Water", International Journal of Hydrogen Energy, pp. 1-16.

[20]. Balat, M. (2008). Potential Importance of Hydrogen as a Future Solution to Environmental and Transportation Problems. International Journal of Hydrogen Energy. Vol. 33, Issue 15, pp.4013-4029. doi.org/10.1016/ j.ijhydene.2008.05.047.

[21]. Preez, S. P. and Bessarabov, D. G. (2017). Hydrogen Generation by Means of Hydrolysis Using Activated Al-In-Bi-Sn Composites for Electrochemical Energy Applications. International Journal of Electrochemical Science, Vol. 12, pp. 8663-8682. doi: 10.20964/2017.09.22.

[22]. Macanás, J., Soler, L., Candela, A. M., Muñoz M and Casado, J. (2011). Hydrogen Generation by Aluminium Corrosion in Aqueous Alkaline Solutions Energy, 362493

[23]. Carmo, M., Fritz, D., Mergel, J .and Stolten, D. (2013). "A comprehensive review on PEM water electrolysis". Journal of Hydrogen Energy. 38 (12): 49014934. doi:10.1016/j.ijhydene.2013.01.151.

[24]. Mahmoodi, K. and Alinejad, B. (2010). "Enhancement of Hydrogen Generation Rate in Reaction of Aluminum with Water". International Journal of Hydrogen Energy.

dio.org/10.1016/j.ijhydene.2010.03.016. OCLC 793213751.CS1.

[25]. Sakintuna, B., Lamari-Darkrim, F. and Hirscher, M. (2007). Metal Hydride Material for Solid Hydrogen Storage: A Review. International Journal of Hydrogen Energy, Vol. 32, Issue 9, pp.1121-1140. doi.org/10.1016/j.ijhydene.2006.11.022.

[26]. Esswein, A. J. and Nocera, D. G. (2007). Hydrogen Production by Molecular Photocatalysis. Chem. Rev., 107 4022. doi: 10.1021/cr050193e.

[27]. Bessarabov, D., Human, G., Kruger, A. J., Chiuta, S., Modisha, P. M., du Preez, S. P., Oelofse, S. P., Vincent, I., Van Der Merwe, J., Langmi, H. W., Ren, J. and Musyoka, N. M., (2017). South Africa Hydrogen Infrastructure (HySA Infrastructure) for Fuel Cells and Energy Storage: Overview of a Projects Portfolio. International Journal of Hydrogen Energy. Vol. 42, Issue 19, pp.13568-13588. doi.org/10.1016/j.ijhydene.2016.12.140.

[28]. Leroy, R. L. (1983). "Industrial Water Electrolysis-Present and Future”, International Journal of Hydrogen Energy; Vol 8, pp.17.

[29]. Wang, Y., Narayanan, S. R. and Wu, W. (2017). "Field-Assisted Splitting of Pure Water Based on Deep-Sub-Debye-Length Nanogap Electrochemical Cells". ACS Nano. Vol. 11, Issue 8, pp. 8421-8428. ISSN 1936-0851. PMID 28686412. doi: 10.1021/acsnano.7b04038.

[30]. Florida Solar Energy Centre (2007). "Hydrogen Basics: Production". http://www.fsec.ucf.edu.en

[31]. Altork, L. N. and Busby, J. R. (2010). "Hydrogen Fuel Cells: Part of the Solution. Technology \& Engineering Teacher, Issue 70(2), pp. 22-27.

[32]. Aquarius Education \& Public Outreach (2020). Electrolysis of Salt Water: The Essence of Life. http://aquarius.nasa.gov.

[33]. Ilyukhina, A. V., Ilyukhin, A. S. and Shkolnikov, E. I. (2012). Hydrogen Generation from Water by Means of Activated Aluminium. International Journal of Hydrogen Energy, Vol. 37, Issue 21, pp.16382-16387. doi.org/10.1016/j.ijhydene.2012.02.175.

[34]. Encyclopeadia Britannica (2013). "Hydrogen". Encyclopeadia Britannica Ultimate Reference Suite, Chicago, USA.

[35]. Haynes, W. M. (2012). Handbook of Chemistry and Physics: A Ready-Reference Book of Chemical and Physical Data. 93rd Edition.). Boca Raton, Fla.: CRC. ISBN 9781439880494.

[36]. Light, T. S., Licht, S., Bevilacqua, A. C. and Morash, K. R. (2005). "The Fundamental Conductivity and Resistivity of Water". Electrochemical and SolidState Letters. Vol. 8, Issue 1, E16-E19. doi: 10.1149/1.1836121. ISSN 1099-0062.

[37]. Zumdahl, S. S. and Zumdahl, S. A. (2013). Chemistry. 9th Edition. Cengage Learning. pp. 866. ISBN 978-1-13-361109-7 